\title{
Sosialisasi Antisipasi Penyebaran Covid-19 melalui Buku Panduan dan Vidio Animasi Sebagai Penunjang Stabilitas Perekonomian Masyarakat di Kota Batam
}

\author{
Doni Putra Utama, Dwi Kartikasari, Shinta Wahyu Hati, Bambang Hendrawan, Yosi Handayani, \\ Dian Mulyaningtyas, Adhitomo Wirawan, Andi Erna Mulyana, Mia Syafrina, Ayu Puspitasari, Fandy \\ Bestario Harlan \\ Politeknik Negeri Batam, Batam Centre, Jl. Ahmad Yani, Tlk. Tering, Kec. Batam Kota, Kota Batam, \\ Kepulauan Riau, Indonesia
}

\begin{abstract}
In early 2020, the world was shocked by the spread of new viruses, the new type of corona virus (SARS-CoV-2) and the disease called Coronavirus disease 2019 (COVID-19). Likewise, in the Riau Islands Province Particularly Batam City became a red zone affected by COVID-19, but there are still many local people who do activities to support their families. The service providers focus on making manuals and animation media so that COVID-19 prevention information is conveyed to the local community in order to maintain the economic stability of the community. The purpose of this Community Service Activity is to create, compile and distribute books. Covid-19 prevention non-authoritative guide so that people have awareness and participate in minimizing the spread of corona virus in Batam, designing and distributing animated videos of Covid-19 prevention guide so that people have awareness and participate in minimizing the spread of corona virus in Batam, socializing education guide books and animated videos so that people maintain health and safety in the Covid-19 Pandemic period, socializing educational guide books and animated videos to support the economic stability of the community. The Community Service Program of the Batam State Polytechnic Business Management program has been implemented and is running well which is participated by all groups and sectors in Batam City
\end{abstract}

Keywords: Covid-19, Handbook, Animation Video, Economic Stability

Abstrak - Di awal tahun 2020, dunia digemparkan dengan merebaknya virus baru yaitu corona virus jenis baru (SARS-CoV-2) dan penyakitnya disebut Coronavirus disease 2019 (COVID-19). Begitu juga halnya di Provinsi Kepulauan Riau Khususnya Kota Batam menjadi zonasi merah terdampak COVID-19, akan tetapi masih banyak masyarakat setempat yang melakukan aktivitas demi menghidupi keluarganya. Pembuatan penyusunan buku panduan dan media animasi agar informasi pencegahan COVID-19 tersampaikan kepada masyarakat setempat demi menjaga stabilitas ekonomi masyarakat Adapun tujuan dari Kegiatan Pengabdian Masyarakat ini adalah untuk membuat, menyusun dan menyebarkan Buku Panduan non otoritatif pencegahan Covid-19 agar masyarakat memiliki kesadaran dan berpartisipasi meminimalisir penyebaran virus corona di Batam, merancang dan menyebarkan vidio animasi panduan pencegahan Covid-19 agar masyarakat memiliki kesadaran dan berpartisipasi meminimalisir penyebaran virus corona di Batam, mensosialisasikan edukasi buku panduan dan vidio animasi agar masyarakat menjaga kesehatan dan keselamatan di masa Pandemi Covid-19, mensosialisasikan edukasi buku panduan dan vidio animasi sebagai penunjang stabilitas ekonomi masyarakat. Program kegiatan Pengabdian Kepada Masyarakat Jurusan Manajemen Bisnis Politeknik Negeri Batam sudah dilaksanakan dan berjalan dengan baik yang diikuti oleh seluruh kalangan dan sektor di Kota Batam

Kata Kunci: Covid-19, Buku Panduan, Vidio Animasi, Stabilitas Ekonomi

\section{PENDAHULUAN}


Di awal tahun 2020, dunia digemparkan dengan merebaknya virus baru yaitu corona virus jenis baru (SARS-CoV-2) dan penyakitnya disebut corona virus disease 2019 (Covid-19). Sampai saat ini sudah dipastikan terdapat 213 negara yang telah terjangkit virus satu ini (Data WHO, 20 April 2020). Pada awalnya data epidemiologi menunjukkan 66\% pasien berkaitan dengan satu pasar seafood atau live market di Wuhan, Provinsi Hubei Tiongkok (Huang, et. al., 2020). Wabah ini meluas dengan sangat cepat ke berbagai negara dalam dua minggu kemudian sehingga menjadi pandemi global. Di Indonesia, pandemi virus corona telah ditetapkan pemerintah sebagai bencana nasional pada hari Sabtu 14 Maret 2020 dan Indonesia memasuki masa darurat bencana non alam.

Kasus pertama pasien corona di Indonesia diungkapkan oleh Presiden pada tanggal 2 Maret 2020 menimpa seorang ibu dan anaknya yang tinggal di Depok, begitu juga halnya di Provinsi Kepulauan Riau Khususnya Kota Batam menjadi zonasi merah terdampak Covid-19, akan tetapi masih banyak masyarakat setempat yang melakukan aktivitas demi menghidupi keluarganya. Untuk dikota Batam Pemerintah Kota Batam telah menetapkan 5 kecamatan yang ditetapkan sebagai daerah zona merah, yaitu: Kecamatan Batam Kota, Kecamatan Batuaji, Kecamatan Sagulung, Kecamatan Bengkong, Kecamatan Sekupang (Sumber: batampos.co.id).

Berdasarkan latar belakang yang sudah dijelaskan di atas maka para pengabdi berfokus pada pembuatan penyusunan buku panduan dan media animasi agar informasi pencegahan Covid-19 tersampaikan kepada masyarakat setempat demi menjaga stabilitas ekonomi masyarakat serta mendukung salah satu amanat menteri yaitu Permendagri Nomor 1 Tahun 2013 tentang pemberdayaan masyarakat melalui gerakan pemberdayaan dan kesejahteraan keluarga Pasal 5 ayat 2 huruf g dan j yaitu kesehatan dan perencanaan sehat. Adapun tujuan dari kegiatan pengabdian masyarakat ini adalah untuk membuat, menyusun dan menyebarkan buku panduan non-otoritatif pencegahan Covid-19 agar masyarakat memiliki kesadaran dan berpartisipasi meminimalisir penyebaran virus corona di Batam, merancang dan menyebarkan vidio animasi panduan pencegahan Covid19 agar masyarakat memiliki kesadaran dan berpartisipasi meminimalisir penyebaran virus corona di Batam, mensosialisasikan edukasi buku panduan dan vidio animasi agar masyarakat menjaga kesehatan dan keselamatan di masa pandemi Covid-19, mensosialisasikan edukasi buku panduan dan vidio animasi sebagai penunjang stabilitas ekonomi masyarakat. 


\section{TINJAUAN PUSTAKA}

\subsection{Pengertian COVID-19}

Dalam Yuliana (2020), coronavirus adalah kumpulan virus yang bisa menginfeksi sistem pernapasan. Pada banyak kasus, virus ini hanya menyebabkan infeksi pernapasan ringan, seperti flu. Namun, virus ini juga bisa menyebabkan infeksi pernapasan berat, seperti pneumonia. 2019-nCoV atau dikenal juga dengan novel coronavirus menyebabkan wabah pneumonia di kota Wuhan, Tiongkok pada Desember 2019, dan menyebar ke negara lainnya hingga Januari 2020.

Coronavirus bersifat sensitif terhadap panas dan secara efektif dapat diinaktifkan oleh desinfektan mengandung klorin, pelarut lipid dengan suhu $56^{\circ} \mathrm{C}$ selama 30 menit, eter, alcohol, asam perioksia perioksiasetat, detergen non-ionik, formalin, oxidizing agent dan kloroform. Klorheksidin tidak efektif dalam menonaktifkan virus (Korsman, 2012).

\subsection{Buku Panduan}

Menurut Effendy (2017) buku pedoman atau panduan adalah buku yang berisi informasi, petunjuk, dan lain-lain yang menjadi petunjuk tuntunan bagi pembaca untuk mengetahui sesuatu secara lengkap. Jadi berdasarkan pendapat diatas dapat diartikan bahwa buku panduan merupakan penuntun bagi pembaca untuk melakukan sesuatu atau berkecimpung di suatu lingkungan baru karena di dalam buku panduan tersebur terdapat informasi-informasi yang dibutuhkan sehingga pembaca tidak hanya mengetahui dan memahami saja namun pembaca dapat menerapkan informasi tersebut. Demikian halnya dengan buku panduan yang akan dihasilkan dari kegiatan pengabdian ini diharapkan mesyarakat dapat mengerti dan memahami bahayanya virus Covid-19 ini dan dapat menerapkan tata cara pencegahan virus ini dalam kehidupan sehari-hari.

Dengan membaca buku petunjuk penggunaan, kita akan memperoleh manfaat (sumber: utakatikotak.com):

1. Mengetahui dan mengoptimalkan fungsi-fungsi dan fitur apa saja yang ada didalamnya.

2. Menghindari resiko kecelakaan.

3. Untuk mengatasi suatu masalah.

4. Mendapatkan manfaat yang maksimal dari peralatan tersebut.

\subsection{Animasi}


Menurut Ibiz Fernandez (2002) “Animation is the process of recording and playing back a sequence of stills to achieve the illusion of continues motion". Yang artinya kurang lebih adalah: "Animasi adalah sebuah proses merekam dan memainkan kembali serangkaian gambar statis untuk mendapatkan sebuah ilusi pergerakan.” Berdasarkan arti harfiah, animasi adalah menghidupkan. Yaitu usaha untuk menggerakkan sesuatu yang tidak bisa bergerak sendiri.

Saat ini istilah animasi sudah tidak awam lagi, karena kita biasa melihat animasi ditayangkan di televisi ataupun di internet, pada umumnya orang-orang mengetahui animasi lewat film-film yang ditontonnya, karena film sekarang semakin sering diproduksi dan banyak yang menyukai.

\section{Jenis-Jenis Animasi}

Ada beberapa jenis-jenis animasi antara lain sebagai berikut (sumber: bieproduction.com):

A. Jenis animasi berdasarkan bentuk karakter yang dibuatnya yaitu Stop Motion

Animation/Claymation, Animasi 2 Dimensi/2D, Animasi 3 Dimensi/3D, Animasi Jepang

B. Manfaat Animasi

Adapun manfaat dari animasi adalah sebagai berikut:

- Dapat menampilkan secara visual baik dalam bentuk gambar atau animasi sebuah zat atau objek yang sangat kecil dan tidak mungkin dilihat dengan mata telanjang seperti bentuk ion, molekul, mikro organisme, sel dan lain-lain.

- Dapat menampilkan secara visual dan audio dalam bentuk animasi, gambar atau vidio sebuah objek yang besar dan jauh seperti hewan buas, bentuk permukaan bumi (gunung, sungai dan lain-lain) dan benda luar angkasa (planet, satelit).

- Dapat menyajikan benda atau peristiwa yang kompleks, rumit dan berlangsung cepat atau lambat, seperti sistem tubuh manusia, bekerja suatu mesin, beredarnya planet mars, berkembangnya bunga dan lain-lain.

- Dapat menyajikan bentuk animasi dan simulasi dari benda atau peristiwa yang berbahaya, seperti bencana alam (gempa, gunung berapi) dan peristiwa perang.

- Dapat menyajikan berbagai simulasi yang rumit dalam bidang ilmu pengetahuan dan bidang teknik yang apabila disimulasikan ke dunia nyata cukup mahal. 
- Dengan animasi, dapat mempermudah belajar materi yang rumit menjadi lebih mudah dipahami dan dibayangkan. Animasi biasa berbentuk simulasi, eksperimen atau prosedur. Dengan animasi, kita mudah mengerti dan memahami suatu proses yang sulit diterjemahkan oleh teks dan gambar seperti proses pembelahan sel, proses kimiawi dan lain-lainnya.

- Melalui vidio, kita mampu mempelajari keadaan riil dari suatu proses, fenomena atau kejadian. Kita dapat melakukan replay pada bagian-bagian tertentu untuk melihat gambaran yang lebih fokus. Hal ini sulit diwujudkan bila vidio disampaikan melalui media seperti televisi. Vidio mampu menunjukkan dengan jelas suatu langkah procedural, misalkan dengan cara melukis suatu segitiga sama sisi dengan bantuan jangka.

\section{METODE PELAKSANAAN PENGABDIAN}

Kegiatan pengabdian pada masyarakat ini ditujukan untuk meminimalisir penyebaran Covid-19 dan berupaya menunjang stabilitas ekonomi masyarakat Provinsi Kepulauan Riau khususnya Kota Batam jika ingin beraktivitas untuk menghidupi sehari-harinya. Kemudian metode yang digunakan dalam kegiatan ini adalah edukasi melalui buku panduan dan edukasi melalui media animasi ke masyarakat Batam. Hasil pembuatan media animasi akan disosialisasikan melalui media online, media sosial polibatam, grup media sosial, website Polibatam, Vidio Tron dan Polibatam TV. Selain itu buku panduan akan dibagikan ke masyarakat Batam dan instansi atau masyarakat komunitas di Batam. Buku panduan dan animasi juga akan di informasikan ke instansi atau komunitas dengan melibatkan pihak kerjasama dan humas Polibatam.

Dalam Pengerjaan kegiatan pengabdian ini diupayakan dalam bentuk online. Apabila dibutuhkan untuk koordinasi secara tatap muka, pelaksanaan akan tetap memperhatikan menjaga jarak sesuai protokol kesehatan dari pemerintah dan protokol WHO.

\subsection{Tahap Perencanaan}

\section{Tahap Pertama:}

a. Tim pengabdi melakukan identifikasi masalah dengan melakukan klasifikasi masalah, sehingga akan memudahkan pemberian solusi dan tepat sasaran dalam pembuatan penyusunan buku dan media animasi. 
b. Tim pengabdi melakukan identifikasi kebutuhan yang terkait pelaksanaan pengabdian masyrakat dalam pelaksanaan koordinasi ini, tim menggunakan koordinasi secara online.

c. Tim pengabdi membagi tugas dan peran dalam penyusunan konten buku dan animasi, tim pengabdi membagi tugas dalam distribusi dan penyebaran informasi. Pada tahap ini pembagian tugas koordinasi dengan tenaga ahli dan pembagian dalam penyusunan laporan.

\subsection{Tahap Pelaksanaan}

\section{Tahap Kedua:}

a. Tim pengabdi menyusun konten vidio animasinya dan menyusun konten isi bukunya sesuai target peserta.

b. Tim pengabdi saling berkoordinasi dalam penyusunan konten buku dan vidio.

c. Tim pengabdi berkoordinasi dengan tenaga ahli saat proses penyusunan konten untuk meminimalisir kesalahan konten

d. Tim melakukan pencetakan dan finishing produk untuk uji kelayakan

\section{Tahap Ketiga :}

a. Tim pengabdi melakukan uji kelayakan dan penilaian dengan melibatkan pakar medis dan pakar animasi agar buku panduan dan vidio animasi yang dibuat sesuai kaidah keilmuan kesehatan dan multimedia sehingga buku panduan layak untuk disebarkan dan didistribusikan kemasyarakat.

b. Melakukan revisi bila ada masukan dan saran untuk perbaikan dari tenaga ahli.

c. Kegiatan ini dilakukan secara online dan ada pertemuan juga dengan tenaga ahli dengan tetap menjaga jarak dan prosedur protokoler kesehatan.

\section{Tahap Keempat:}

a. Tim melakukan persiapan penyebaran buku dan video ke masyarakat. 
b. Tim melakukan edukasi dalam bentuk buku panduan dan media animasi kepada masyarakat Batam dan komunitas dengan melibatkan bagian kerjasama Polibatam dan juga pihak lain.

c. Tim melakukan edukasi kegiatan pengabdian ini melibatkan pihak Humas Polibatam dan bagian kerjasama Polibatam untuk penyebaran ke masyarakat, intansi, dan aliansi komunitas. Semua bukti distribusi dan penyebaran didokumentasikan.

\subsection{Tahap Evaluasi dan monitoring}

\section{Tahap Kelima:}

a. Mengukur sikap dan kesadaran masyarakat melalui kuisioner umpan balik sejauh mana perubahan tingkat kesadaran dan sikap perilaku masyarakat yang menggunakan buku panduan dan animasi.

b. Mengolah data umpan balik sehingga bisa diketahui sejauhmana perubahan sikap dan perilaku setelah membaca dan melihat konten edukasi dari buku dan vidio animasi.

c. Tim membuat progress laporan kemajuan.

\subsection{Tahap Laporan}

6. Tahap Keenam: Tim pengabdi melakukan pembagian tugas untuk menyusun $d r a f t$ artikel, pengajuan HAKI dan pembuatan poster

7. Tahap Ketujuh: Tim berbagi tugas untuk menyusun laporan pengabdian dan publikasi.

\section{HASIL DAN PEMBAHASAN}

Sosialisasi yang dilakukan oleh tim adalah dengan dibuatnya vidio animasi dan buku panduan hal-hal yang harus diperhatikan selama Covid-19, kegiatan ini juga dibantu dengan bantuan alat atau aplikasi zoom untuk dilakukan webinar. Hal tersebut dilakukan karena, tidak dimungkinkan untuk diadakannya kegiatan sosialisasi secara tatap muka, sehingga diperlukan alat untuk dilakukan webinar. Setelah kegiatan ini berakhir, tim memasukkan 
buku panduan, vidio animasi, materi-materi, dan tayangan ulang di website institusi perguruan tinggi Politeknik Negeri Batam.

\subsection{Pembuatan Produk Vidio Animasi}

\section{Prosedur Detail}

1. Tim pengabdian masyarakat memberikan sinopsis cerita pada vidio animasi kepada tim teknis,

2. Tim teknis dan tim pengabdian melakukan breakdown mengenai isi pada vidio animasi,

3. Tim teknis membuat script vidio animasi dan dilakukan review oleh tim reviewer,

4. Pembuataan storyboard oleh tim teknis,

5. Dilakukan proses review dan revisi dari storyboard yang dibuat,

6. Tim teknis melakukan proses;

- Drawing mulai dari key animation, in betweening dan animation checking,

- $\quad$ Backgrounding yakni maping, sket dan painting.

7. Tim teknis melakukan proses coloring dan animating,

8. Review hasil coloring dan animating kemudian tim teknis melakukan proses editing vidio,

9. Tim teknis melakukan pengisian suara dubber dan sound FX,

10. Editing vidio setelah review hasil dubber dan sound $F X$,

11. Finishing video release dalam acara webinar sosialisasi antisipasi penyebaran Covid-19 oleh Politeknik Negeri Batam.

\subsection{Pembuatan Produk Buku Panduan}

\section{Prosedur Detail}

1. Ketua program studi menunjuk dan menetapkan ketua tim pengabdian masyarakat,

2. Ketua tim pengabdian menentukan anggota tim,

3. Tim pengabdian masyarakat dan prodi menentukan target dan bentuk pengabdian masyarakat,

4. Penetapan pembuatan buku elektronik sebagai produk dari pengabdian masyarakat,

5. Tim pengabdian masyarakat mencari referensi dan melakukan workshop dengan narasumber ahli dibidangnya untuk pembuatan buku sosialisasi antisipasi penyebaran Covid-19,

6. Review 1 dilakukan oleh pihak internal dari prodi logistik perdagangan internasional, 
7. Proses revisi oleh penulis yakni tim pengabdian terkait review dari internal,

8. Review 2 dilakukan oleh tim internal dan eksternal yakni dari Dinas Kesehatan Pemerintah Provinsi Kepulauan Riau, bapak Susilo Budi Hartanto, S.Si, Apt dan ibu Mardianti, SE, M.Ap,

9. Proses revisi sesuai masukan pada review 2,

10. Cek hasil revisi oleh review internal dan eksternal,

11. Pengumpulan draft final buku elektronik kepada tim teknis,

12. Draft final melalui proses editing dan layout,

13. Setelah itu dilakukan Proofreading oleh tenaga ahli yang dilanjutkan proses pencetakan oleh Polibatampress.

\subsection{Distribusi Buku Panduan dan Vidio Animasi}

Distribusi produk yang dihasilkan adalah dengan cara mensosialiasikan produk tersebut kepada masyarakat. Adapun sosialiasi yang dilakukan adalah sebagai berikut:

\section{Prosedur Detail}

1. Sosialisasi antisiapasi penyebaran Covid-19 menggunakan webinar,

2. Penyampaian tata tertib webinar,

3. Pembukaan acara oleh panitia,

4. Sambutan dari jurusan oleh ketua jurusan manajemen bisnis Polibatam ibu Dwi Kartikasari, ST., M.BA,

5. Sambutan ketua pelaksana dan pemaparan vidio oleh bapak Doni Putra Utama, SE., Ak., M.Si, CA,

6. Pemutaran vidio animasi mengenai antisipasi penyebaran Covid-19,

7. Moderator yakni ibu Dian Mulyaningtyas, S.Si., M.T memulai webinar dengan membacakan profil dari pembicara,

8. Pemaparan materi dan buku panduan oleh pembicara 1 dari Dinas Kesehatan Pemerintah Provinsi Kepulauan Riau, bapak Susilo Budi Hartanto, S.Si, Apt,

9. Pemaparan materi dan buku panduan oleh pembicara 2 dari Dinas Kesehatan Pemerintah Provinsi Kepulauan Riau, ibu Mardianti, SE, M.Ap,

10. Moderator memandu proses tanya jawab peserta webinar,

11. Peserta webinar diminta melakukan pengisian kuesioner penutupan oleh moderator dan panitia. 
Peserta yang mendaftar kegitaan sosialisasi ini sebanyak 95 orang, sedangkan yang mengikuti kegiatan webminar sosialisasi adalah 75 orang, serta yang melakukan absensi dan umpan balik adalah sebesar 60 orang.

Untuk mengetahui hasil dari kegiatan tersebut, kami lakukan survey umpan balik agar menjadi evaluasi bagi tim pengabdian masyarakat kedepannya, adapun hasil dari umpan balik yang kami lakukan adalah sebagai berikut:

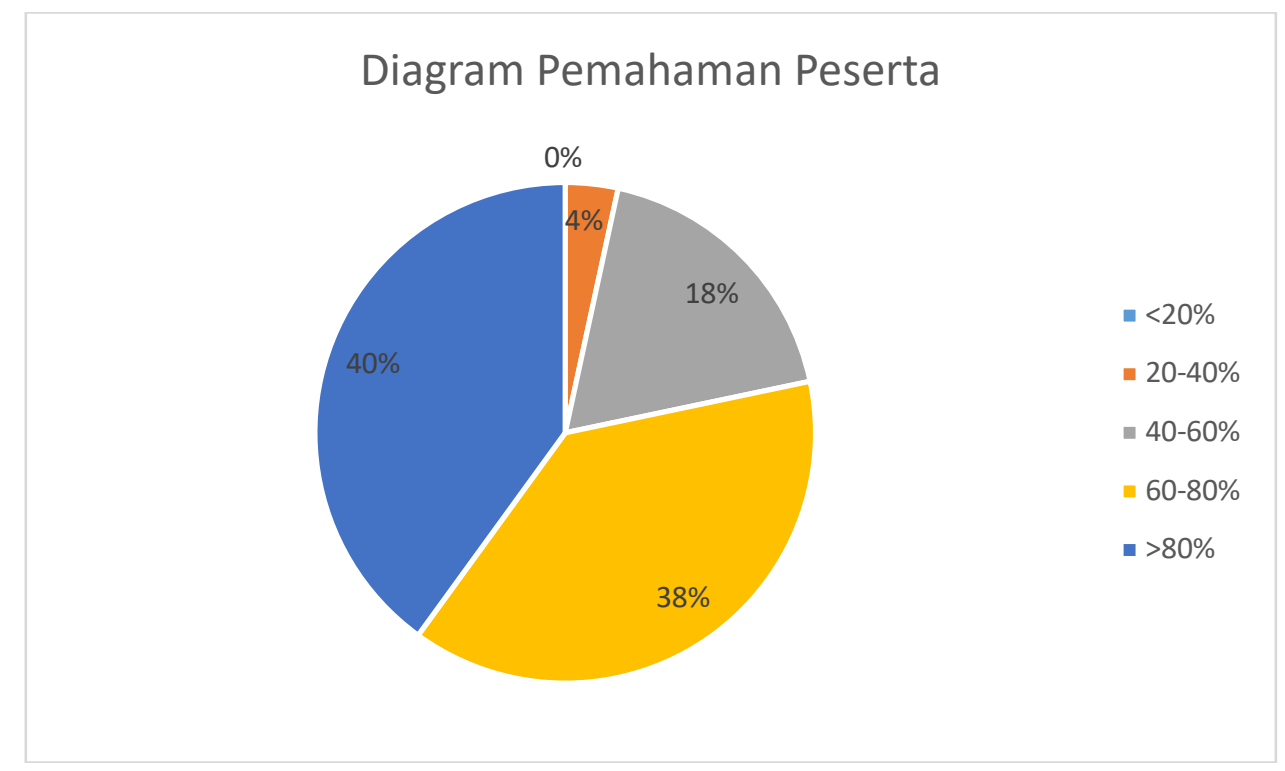

Gambar 1. Diagram Pemahaman Peserta

Pemahaman yang didapat oleh peserta setelah dilakukan kegiatan ini sangat bervariatif, dapat dilihat dari range sebagai berikut:

\begin{tabular}{|c|l|}
\hline Range & \multicolumn{1}{|c|}{ Kategori } \\
$<20 \%$ & Tidak memahami \\
$20-40 \%$ & Kurang memahami \\
$40-60 \%$ & Cukup memahami \\
$60-80 \%$ & Memahami kegiatan \\
$>80 \%$ & Sangat memahami kegiatan \\
\hline
\end{tabular}

Terdapat 3,4\% yang kurang memahami kegiatan, dikarenakan peserta dalam kategori ini merupakan peserta dibawah umur yaitu sebanyak 2 peserta, sebesar 18,3\% untuk kategori cukup memahami yaitu sebanyak 11 orang peserta, hal ini disebabkan antusias peserta terhadap waktu pelaksanaan kegiatan yang singkat, sebanyak 38,3\% peserta dari kegiatan ini memahami kegiatan yang dilaksanakan, karena sebanyak 23 orang berprofesi sebagai 
pekerja, pelajar, pendidik, petugas kesehatan, pemerinah, dan lainnya. Selebihnya sebesar $40 \%$ peserta yaitu sebanyak 24 orang sangat memahami kegiatan sosialisasi tersebut.

Dibawah ini adalah hasil umpan balik dari peserta atas produk yang dihasilkan dari pengabdian masyarakat, yaitu Vidio Animasi dan Buku Panduan hal-hal yang diperhatikan selama pandemik COVID-19, sebagai berikut:

\section{Vidio Animasi Memberikan Pengetahuan Baru}

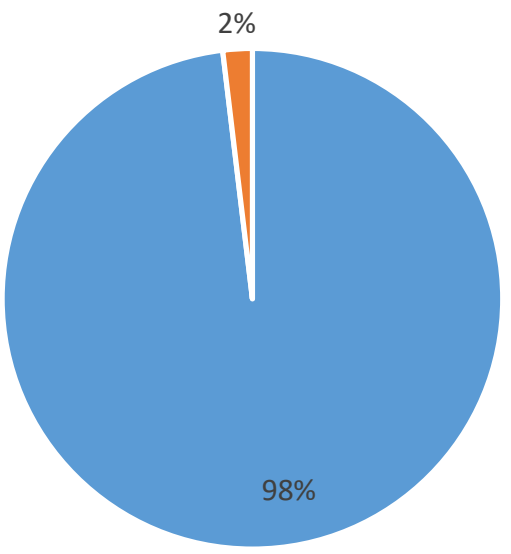

$$
\begin{aligned}
& \text { - Ya } \\
& \text { - Tidak }
\end{aligned}
$$

Gambar 2. Diagram Pengetahuan Baru peserta terhadap Vidio Animasi

Sebanyak 59 orang atau 98,1\% dari peserta mendapatkan pengetahuan baru dari produk vidio animasi yang dibuat, hal ini dimungkinkan ketertarikan peserta terhadap penyampaian informasi sosialisasi melalui media audio visual dan sisanya sebesar 1,9\% terdapat peserta yang merasa tidak mendapatkan pengetahuan baru dikarenakan kebanyakan peserta tertarik untuk membaca. Hal ini bisa dilihat pada diagram buku panduan dibawah.

\section{Buku Panduan Memberikan Pengetahuan Baru}

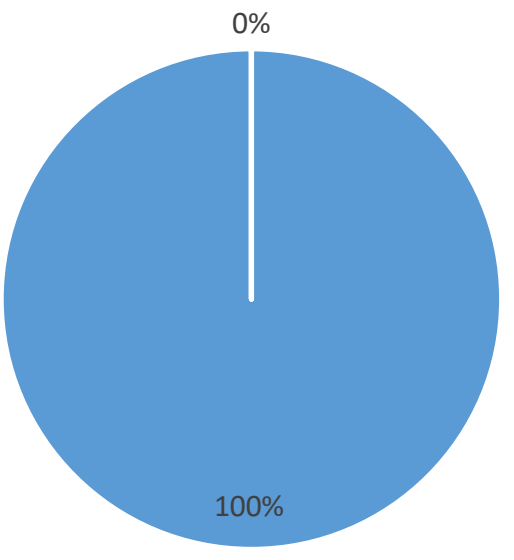

$$
\begin{aligned}
& \text { - Ya } \\
& \text { - Tidak }
\end{aligned}
$$

Gambar 3. Diagram Pemahaman peserta terhadap Buku Panduan 
Pengetahuan baru dari buku panduan yang dibuat kepada peserta mendapatkan respon yang sangat baik, dimana seluruh peserta merespon bahwa dari buku panduan yang dibuat, peserta mendapatkan pengetahuan baru terkait hal-hal yang harus diperhatikan selama pandemik Covid-19. Hal ini juga membuktikan bahwa buku panduan sangatlah efektif untuk menyampaikan hal-hal informatif terhadap pengguna atau peserta dibandingkan dibuatnya media audio visual guna menambahkan pengetahuan baru. Tanggapan dari peserta juga membutikan bahwa buku adalah jendela dunia dan kegiatan membaca buku merupakan suatu cara untuk membuka jendela tersebut agar kita bisa mengetahui lebih tentang dunia yang belum kita ketahui sebelumnya, apalagi terkait hal-hal yang harus diperhatikan selama pandemik Covid-19 berlangsung seperti: wajib menggunakan masker dimanapun dan kapanpun, wajib untuk selalu mencuci tangan kita dengan sabun dan dengan air mengalir yang bersih, dan menjaga jarak 1-2 meter dengan orang lain dari suatu kerumunan atau di tempat umum.

\section{KESIMPULAN}

\subsection{Kesimpulan}

Dengan adanya sosialisasi ini diharapkan masyarakat dapat memutus mata rantai penyebaran Covid-19 sebagai penunjang stabilitas perekonomian di Kota Batam. Maka dari itu, pengabdian ini memberikan pengetahuan dan keterampilan mengenai hal-hal yang harus diperhatikan selama pandemic Covid-19 berlangsung dengan diciptakannya suatu produk buku panduan dan animasi agar mudah untuk dipahami oleh masyarakat.

Program kegiatan pengabdian kepada masyarakat jurusan manajemen bisnis Politeknik Negeri Batam sudah dilaksanakan dan berjalan dengan baik yang diikuti oleh seluruh kalangan dan sektor di Kota Batam. Kegiatan yang telah dilaksanakan antara lain sosialisasi melalui animasi, buku panduan, praktik mencegah penyebaran, serta mengundang narasumber dari anggota tim gugus tugas percepatan penanganan Covid-19 Kepulauan Riau dalam hal ini adalah Dinas Kesehatan Provinsi Kepulauan Riau. Masyarakat Batam sangat senang dengan program pengabdian yang telah berlangsung dan mengharapkan adanya kelanjutan dari program pengabdian masyarakat yang akan datang.

\section{DAFTAR PUSTAKA}


Republik Indonesia. 2013. Peraturan Kementerian Dalam Negeri No.1 Tahun 2013 Tentang Pemberdayaan Masyarakat melalui gerakan pemberdayaan dan kesejahteraan keluarga, Jakarta Korsman, S.N.J., van Zyl, G.U., Nutt, L., Andersson, M.I, Presier, W. (2012). Viroloy. Chins: Churchill Livingston Elsevier

Yuliana, 2020. Wellness and Healthy Magazine. "Corona Virus Diseases (Covid-19); Sebuah tinjauan literatur". Volume 2 No.1 February 2020, p.187-192

Effendy, Onong Uchjana. (2017). Ilmu Komunikasi Teori dan Praktek, Jawab Barat. Rosda.

McGraw, Ibiz Fernandez, (2002). Macromedia Flash Animation and Cartooning:

A Creative Guide. Hill/Osborn, California

Utakatikotak (2015). https://utakatikotak.com

Batampos (2020). https://batampos.co.id

Bieproduction (2020). https://bieproduction.com 